Matematikai Közlemények

VI. kötet, 2018

doi:10.20312/dim.2018.04

\title{
A talajszerkezeti és spektrális tulajdonságok összefüggésének meghatározása
}

\author{
Kalmár János \\ MTA CSFK GGI \\ kalmar@ggki.hu \\ Neményi Miklós \\ Széchenyi István Egyetem \\ nemenyi.miklos@sze.hu \\ Nyéki Anikó Éva \\ Széchenyi István Egyetem \\ nyeki.aniko@sze.hu
}

\begin{abstract}
ÖSSZEFOGLALÓ. A mezőgazdasági termőtalajok hasznosítása és müvelése a talajösszetétel alapján történik. A talajparaméterek meghatározása helyszíni mintavétellel és a talajminták laboratóriumi elemzésével történik. Ez költséges és hosszadalmas eljárás, ezért megvizsgáltuk, helyettesíthetö-e hiperspektrális (digitális) felvételek készítésével és kiértékelésével.

ABSTRACT. Utilization and cultivation of agricultural soils is done on the basis of the soil composition. Soil parameters are determined by on-site sampling and by laboratory analysis of soil samples. This is a costly and lengthy procedure, so we have examined whether it can be replaced by making hyperspectral (digital) images and evaluating them.
\end{abstract}

\section{Bevezetés}

A precíziós mezőgazdaság egy technológia, amelyik úgy segíti a mezőgazdasági termelés optimalizálását, hogy a művelési táblákat kisebb egységekre lebontva „sűrü” mérési adatok alapján támogatja a döntés-elökészítést.

Két parcellán folytattunk adatgyüjtést, összesen 21 mintavételi helyen. A talajmintákat laboratóriumban értékeltük ki 17 összetevőre (talajparaméterre) vonatkozólag, melyből a sótartalmat állandósága miatt elhagytuk. A mintavételi helyeken hiperspektrális felvételeket is készítettünk a $(350,2500)$ nm hullámhosszú tartományban, 1 nm felbontással [1], [2].

Hiperspektrális felvétel müszerhiány miatt csak 13 mintavételi helyen készült, viszont pontonként két példányban: az egyik felvétel a bolygatlan (normál) talajfelszínröl, a másik pedig a simítottról készült. Müszerhiba miatt az 1835 nm és 1905 nm hullámhosszú reflexiók közül 34 darab simított és 39 darab normál talajról készült adatot töröltünk.

KULCSSZAVAK. Precíziós mezőgazdaság, talajparaméterek meghatározása, hiperspektrális képek. KEYWORDS. Precision agriculture, determination of soil parameters, hyperspectral images. 


\section{A hiperspektrális képek vizsgálata}

Először összehasonlítottuk a hiperspektrális reflexiók szomszédos hullámhosszait: várakozásainknak megfelelően az kaptuk, hogy a reflexiók korrelációja a szomszédos hullámhosszakon nagyon magas, csak az esetek 5 \%-ban (106 mérési ponton) volt kisebb 0,99-nál. Elgondolkodtató eredményre vezetett a normál és simított reflexiók elkülönített összehasonlítása: a szomszédos adatsorok korrelációinak átlaga ugyan alig különbözik $(0,9961$ - 0,9963), viszont a korrelációk szórása $(0,054-0,049)$, és különösen a minimuma már szignifikánsan eltér $(0,304$ - 0,594), ami a simított talajról felvett adatsorok előnyét (robusztusságát) mutatja.

Az un. főkomponens analízis (továbbiakban PCA) képes az adatsorok számát varianciavesztés nélkül csökkenteni, ezért főkomponens analízissel (PCA) vizsgáltuk meg a spektrális adatsorok $20 \mathrm{~nm}$ szélességü összefüggő (szomszédos) nyalábjait. A PCA az adatsorok keresztkorrelációs (vagy kovariancia) mátrixán alapul, mely mátrix sajátértékei mutatják a főkomponensek fontosságát, a fökomponenseket pedig az eredeti adatsorok olyan lineáris kombinációjaként állítja elő, ahol a súlyok a sajátvektor komponensei. Tudjuk, hogy a kovariancia mátrix pozitív szemidefinit, ezért minden sajátértéke pozitív, és a sajátértékek összege megegyezik a mátrix méretével.

- Vizsgálatunkban a kovariancia mátrix sajátértékeinek összege elméletileg 20, de a legfontosabb komponens sajátértéke általában közel húsznak (>19) adódott, ezért a többi fökomponens szerepe elhanyagolható.

- A legnagyobb sajátértékhez tartozó sajátvektor koordinátái közelítőleg egyformák voltak, ami a sajátérték dominanciájával együtt azt jelenti, hogy a szomszédos 20 spektrális adatsor információ-vesztés nélkül helyettesíthető az átlagukkal.

- A kivételek közé tartozott a $(2474,2500)$ nm hullámhosszú intervallum: az itt elvégzett PCA szerint a $27 \mathrm{~nm}$ széles spektrális adatsort legalább 2 fökomponens adatsorral (sajátértékeik 17.8 és 3,1) kell helyettesíteni könyökszabály értelmében (1. ábra):

- A domináns sajátvektor komponensei most is közel egyenlőnek bizonyultak (átlag: 0.19, szórás: 0.037, 2. ábra)

- A második sajátvektor komponensei már nem egyformák, és előjelben is igen változatosak, a sajátvektorok egyben bázisvektorok is, ezért skaláris szorzatuk 0 .

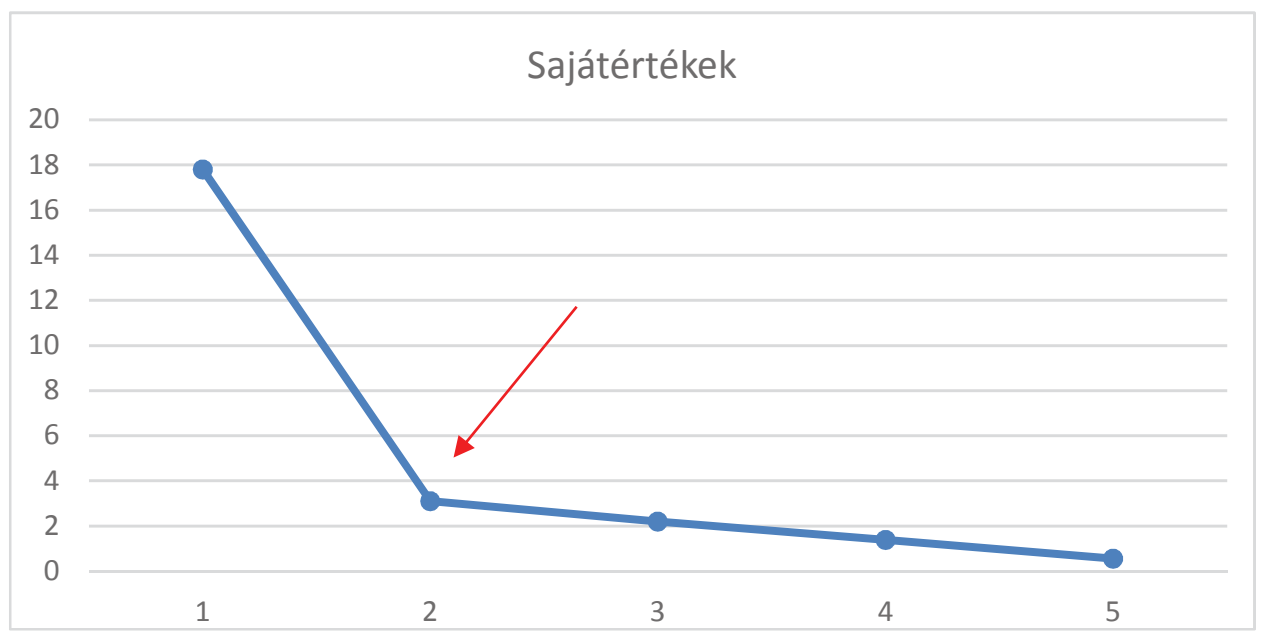

1. ábra. A domináns sajátvektorokat a sajátértékekre alkalmazott könyökszabály jelöli ki 


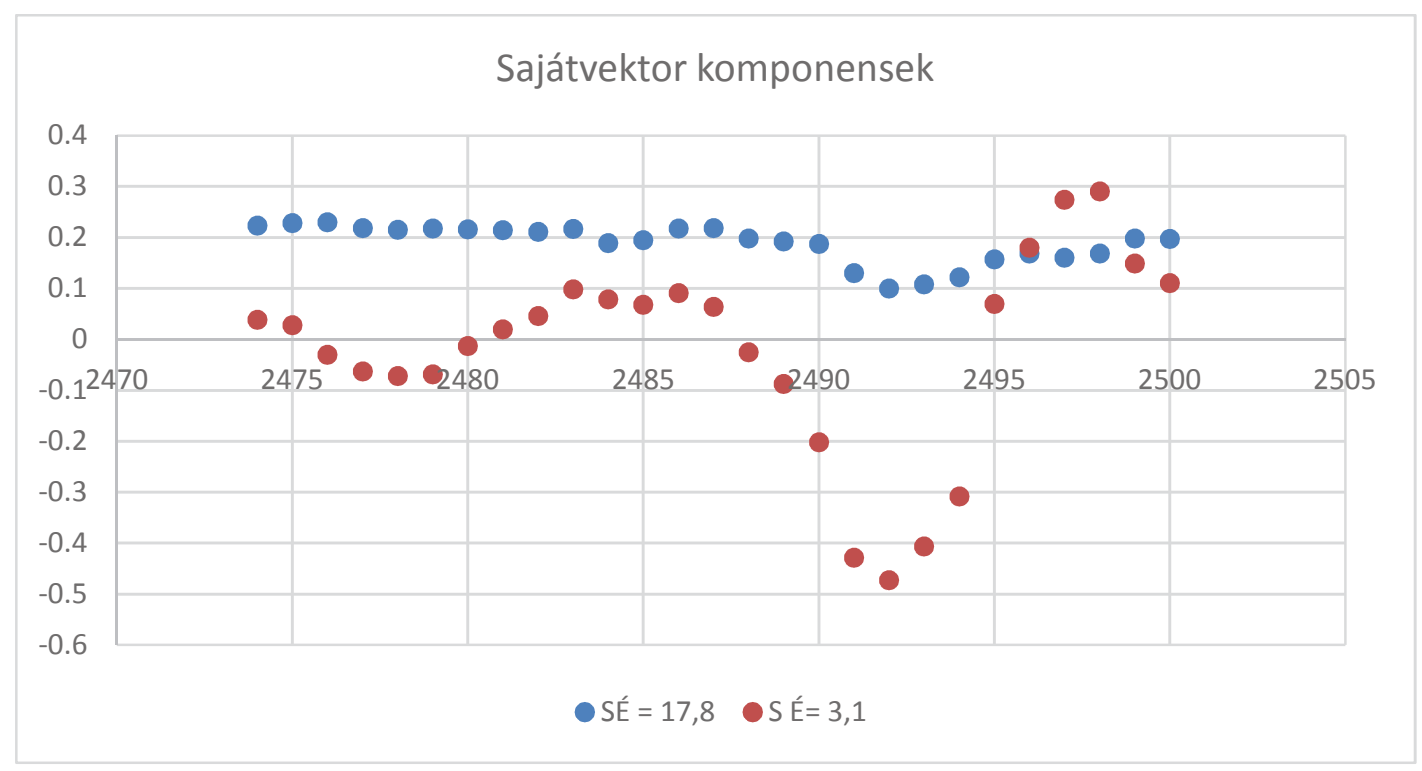

2. ábra. (2474 - 2500) nm hullámhosszokhoz számolt PCA két domináns sajátvektora

A tapasztaltak miatt tehát nem állítható az, hogy minden rövidebb spektrumtartományban mért reflexiókat variancia-vesztés nélkül helyettesíthetünk a reflexiók átlagával, de a domináns sajátvektor komponensei közel egyenlőnek bizonyultak, vagyis a legfontosabb helyettesítő adatsor (lineáris kombináció) mindig az átlag.

Ezután meghatároztuk a 2120 db spektrális adatsor keresztkorrelációs mátrixát. A mátrix minden sorából (tehát hullámhosszanként) egy 20 oszlopos hisztogramot (gyakoriság függvényt) készítettünk. A 20 pontos gyakoriság függvényeket az átlag, ferdeség és csúcsosság/6 statisztikákkal jellemeztük (3. - 4. ábrák).

- A statisztikák diagramja rámutatott arra, hogy a görbék többnyire nyugodt, stabil szakaszokból állnak, a spektrum elején (kb. 1000 nanométerig) - az átlag kivételével növekvő hullámzást mutatnak. Csak a simított képeken látunk intenzív kilengést az 1115-1150 nanométer hullámhossz tartományban, viszont 1350 és 1450 nanométer hullámhosszok között, 1800 és 1950 nanométer hullámhosszok között, és a spektrum végén (2400 nanométer fölött) mindegyik statisztika intenzív kilengést mutat.

- A hisztogramok a korrelációs mátrix sorai alapján készültek, ezért a kilengések arra utalnak, hogy a spektrum csak a jelzett hullámhossz tartományokban érzékeny a mérési pozícióra, tehát a talaj tulajdonságainak változására.

\section{A talaj-összetevők laboradatainak vizsgálata}

- A mért 16 talajparaméterre is főkomponens analízist alkalmaztunk, hogy feltárjuk a közöttük található rejtett összefüggéseket.

- A könyökszabály szerint (5. ábra) a laboradatok már három főkomponenssel leírhatók.

- A 6. ábrán láthatók a legnagyobb sajátértékekhez tartozó sajátvektorok.

- A 7-8. ábrákon a talajösszetevők már fontosságuk (sajátértékkel szorzott sajátvektor komponensek összegeként meghatározott) sorrendjében láthatók. 


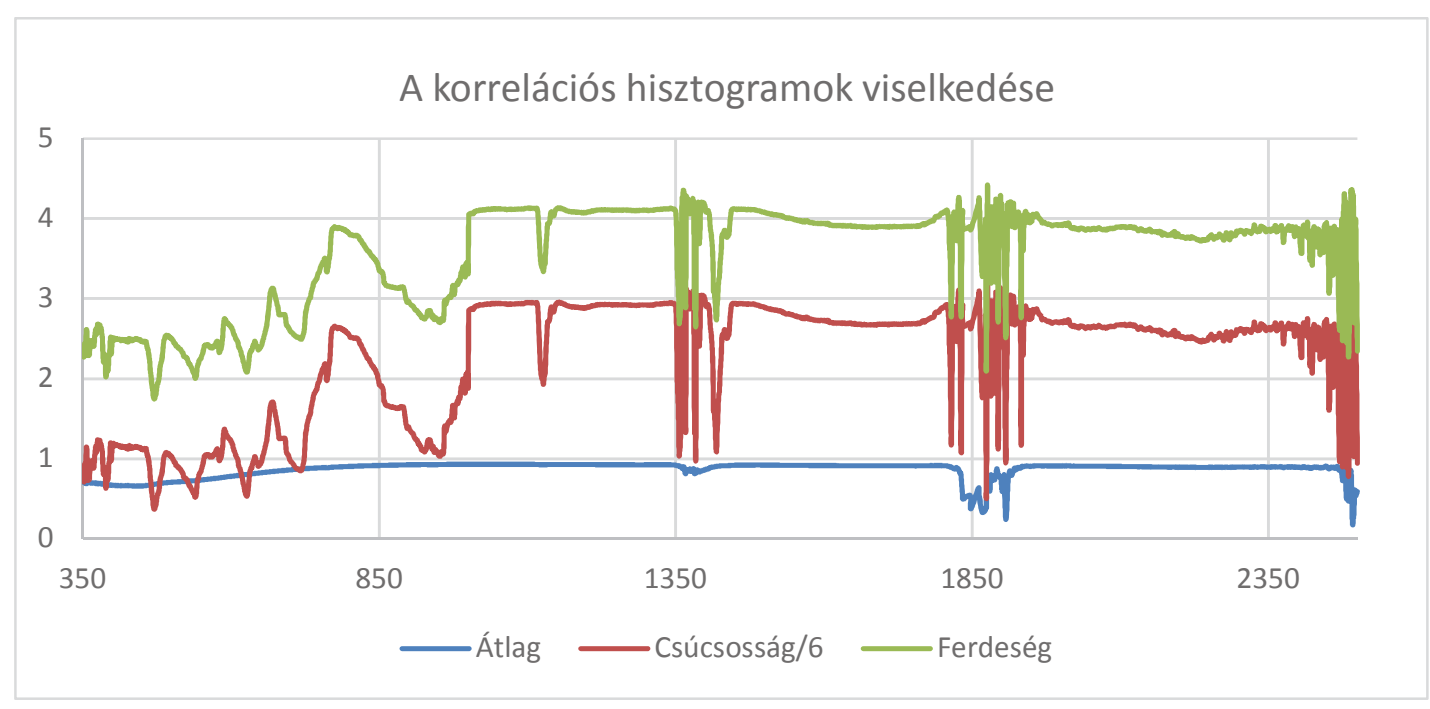

3. ábra. A simított talajú képek statisztikái

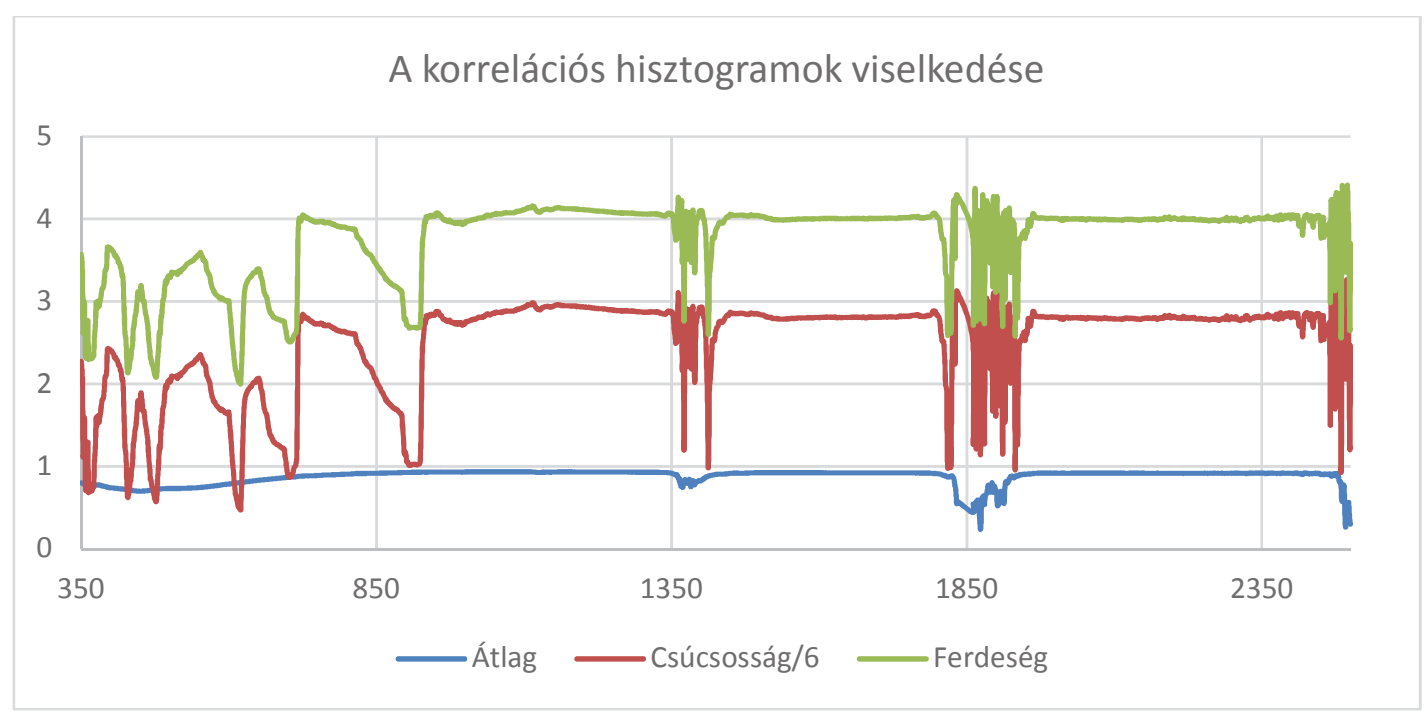

4. ábra. A normál talajú képek statisztikái

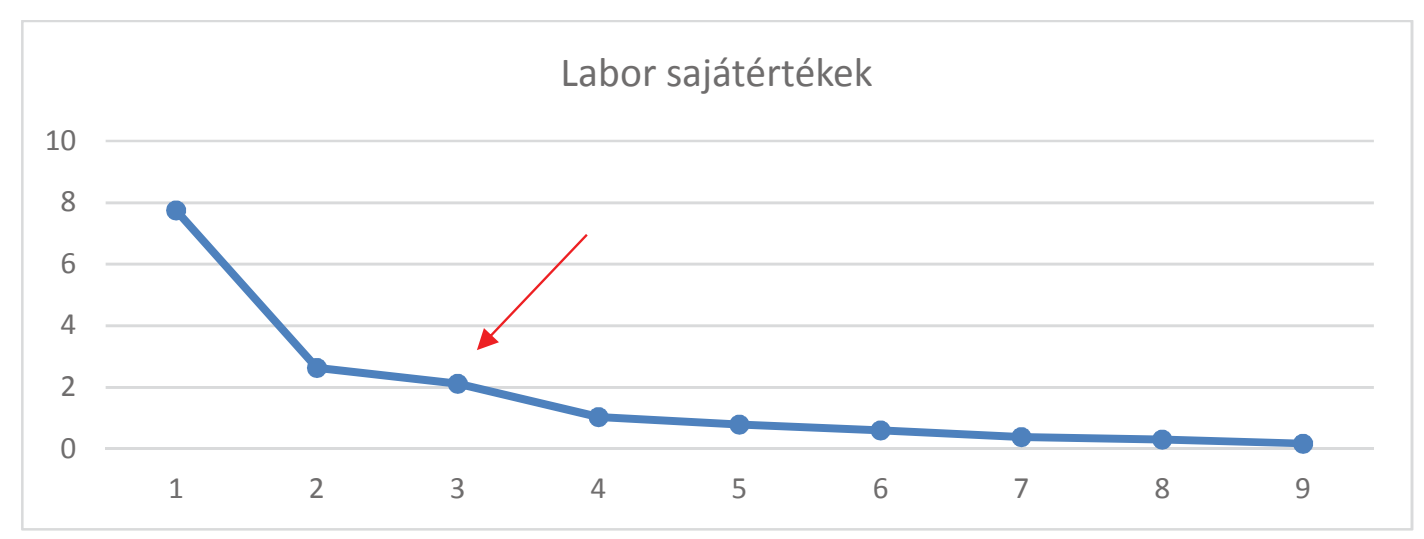

5. ábra. A domináns sajátvektorokat a sajátértékekre alkalmazott könyökszabály jelöli ki 


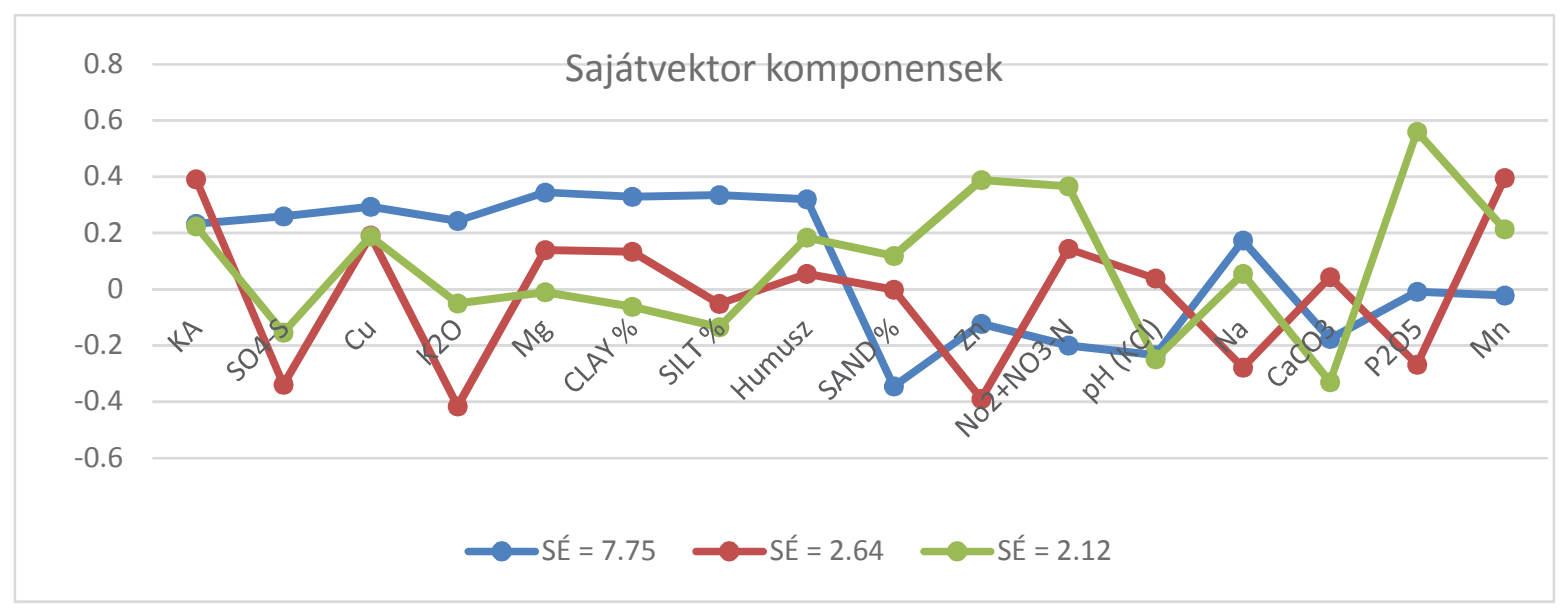

6. ábra. A laboradatokból számolt PCA legfontosabb sajátvektorai

\section{A hiperspektrális és a laboradatok kapcsolata}

A képi és laboradatok kapcsolatát úgy határoztuk meg, hogy korrelációt számítottunk minden hullámhossz-reflexió és minden labor adatsor (a komponensek mérési-hely függők) között. A korrelációk csak szűk hullámhossz tartományokban mutattak (abszolút értékben) 0,5-nél nagyobb értékeket, ezért a spektrummal kapcsolatos korábbi PCA-k alapján feltételeztük, hogy a spektrális adatok legfeljebb tíz hullámhossznyi összefüggő tartománya helyettesíthető a spektrális adatok átlagával. Minden labor-adatsorhoz megkerestük azon 1, 2, ..., 10 hosszú hullámhossz tartományt, ahol a labor-adatsor és a reflexiók átlagának korrelációja (abszolút értékben) maximális volt. A 10 maximum tartomány közül választottuk ki ezután a legjobb korrelációjút. Az eredményeket az 1. táblázatban foglaltuk össze, és a 7. - 8. - 9. ábrákon szemléltettük - természetesen a normál és a simított talajról készült felvételeket végig megkülönböztettük. Látható, hogy csak $\mathrm{N}$ és Mn talajparaméterek esetén korrelál lényegesen jobban $(\approx 0.1)$ a labor adat a normál talajról készült képpel, mint a simított talajjal. Ettől eltekintve a laboradatok és a simított talajról készült felvételek átlagosan 0.075-tel jobb korrelációt mutatnak, mint a normál talaj esetén.

További érdekes megfigyelés, hogy a normál talajról készült képeknél az optimális korrelációhoz 10 talaj-összetevőnél csak egy hullámhosszat szabad figyelembe venni, és 5 esetben két szomszédost. A simított talajnál a spektrális környezet jobban korrelál a talajösszetevővel, 7 esetben kell egy hullámhosszat figyelembe venni, 3 esetben pedig legalább kettöt, de 7 hh is elöfordul (KA).

Vegyük észre, hogy K2O és SO4-S talaj-összetevőket ugyanazon az 1849-es hullámhosszon a legbiztosabb észlelni, sőt, ugyanazon korrelációval. Ugyanezt figyelhetjük meg az Mg és Clay összetevőknél is - vajon nincs közöttük valami direkt kapcsolat? A korrelációszámítás szerint igen, mert a korrelációjuk 0.93-nál nagyobb. Hasonló megállapítást tehetünk, ha megvizsgáljuk Sand és Silt összetevők kapcsolatát. Sand talajparaméter hullámhossz tartománya tartalmazza Silt-ét, és korrelációjuk összege közelítőleg 0. Ebben az esetben az adatsorok közötti korreláció (- 0.97) még erősebb is, mint az elöző példákban. 
Végeredményben a szerzők azt javasolják, hogy a spektrális mérések csak simított talajon történjenek, mert:

- a mérések (illetve átlaguk) jobban korrelálnak a laboradatokkal,

- a szélesebb optimális hullámhossz tartományok átlagolása nagyobb hibatürést (robusztusságot) eredményez,

- csak az $(1841,1870)$ és $(2474,2500)$ hullámhossz tartományokat érdemes mérni, viszont normál talajon a $(1831,1910)$ és $(2463,2482)$ tartományokon kívül szükség van a 446 és 873 nanométeres hullámhosszakra is.

\begin{tabular}{||l||c|c|c|c|c|c||}
\hline Labor adat & korr/simított & kezdő hh & utolsó hh & korr/normál & kezdő hh & utolsó hh \\
\hline \hline pH (KCl) & 0,74404744 & 2494 & 2494 & 0,66945753 & 1909 & 1909 \\
\hline KA & $-0,82240143$ & 2493 & 2499 & $-0,77818156$ & 2482 & 2482 \\
\hline CaCO3 & 0,75805876 & 1851 & 1853 & 0,73946585 & 1901 & 1901 \\
\hline Humusz & $-0,82147033$ & 2492 & 2497 & $-0,62540187$ & 873 & 873 \\
\hline No2+NO3-N & 0,57043033 & 1869 & 1870 & $-0,6714987$ & 1855 & 1858 \\
\hline P2O5 & 0,71732301 & 1858 & 1858 & $-0,61360923$ & 446 & 446 \\
\hline K2O & $-0,76824831$ & 1849 & 1849 & $-0,66255002$ & 1849 & 1849 \\
\hline Na & 0,58352248 & 2498 & 2500 & 0,47748388 & 1851 & 1852 \\
\hline Mg & $-0,88173063$ & 2475 & 2475 & $-0,87102881$ & 1831 & 1831 \\
\hline Cu & $-0,77196251$ & 2474 & 2475 & $-0,75079347$ & 1900 & 1901 \\
\hline Zn & 0,77043110 & 1857 & 1858 & 0,73627430 & 1831 & 1832 \\
\hline Mn & $-0,46224779$ & 1859 & 1859 & $-0,56489117$ & 1858 & 1859 \\
\hline SO4-S & $-0,77323049$ & 1849 & 1849 & $-0,73280416$ & 1849 & 1849 \\
\hline Sand\% & 0,91297538 & 1841 & 1845 & 0,79055039 & 1909 & 1910 \\
\hline Silt\% & $-0,88239173$ & 1841 & 1844 & $-0,70036498$ & 1910 & 1910 \\
\hline Clay\% & $-0,87035868$ & 2475 & 2475 & $-0,88816105$ & 2463 & 2463 \\
\hline
\end{tabular}

1. táblázat. A legjobb korrelációk a labor és a spektrális adatok között

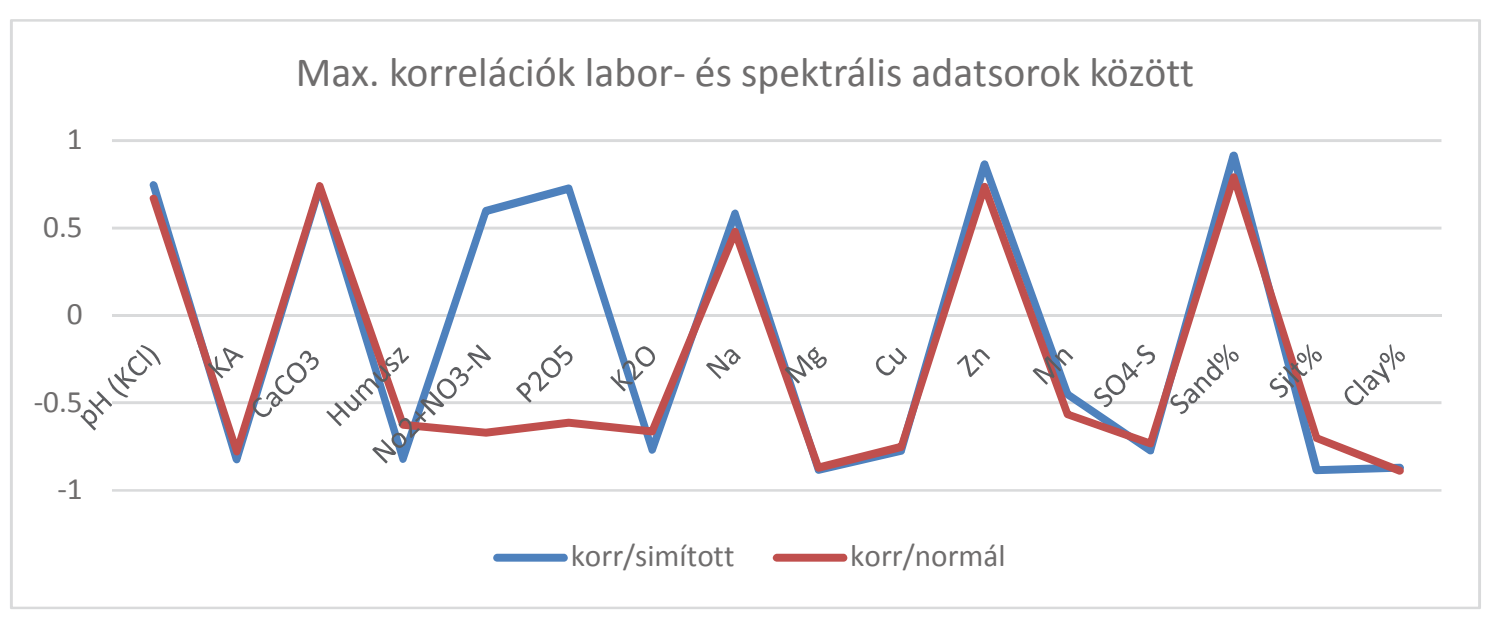

7. ábra. A labor- és spektrális adatsorok legerôsebb kapcsolatai 


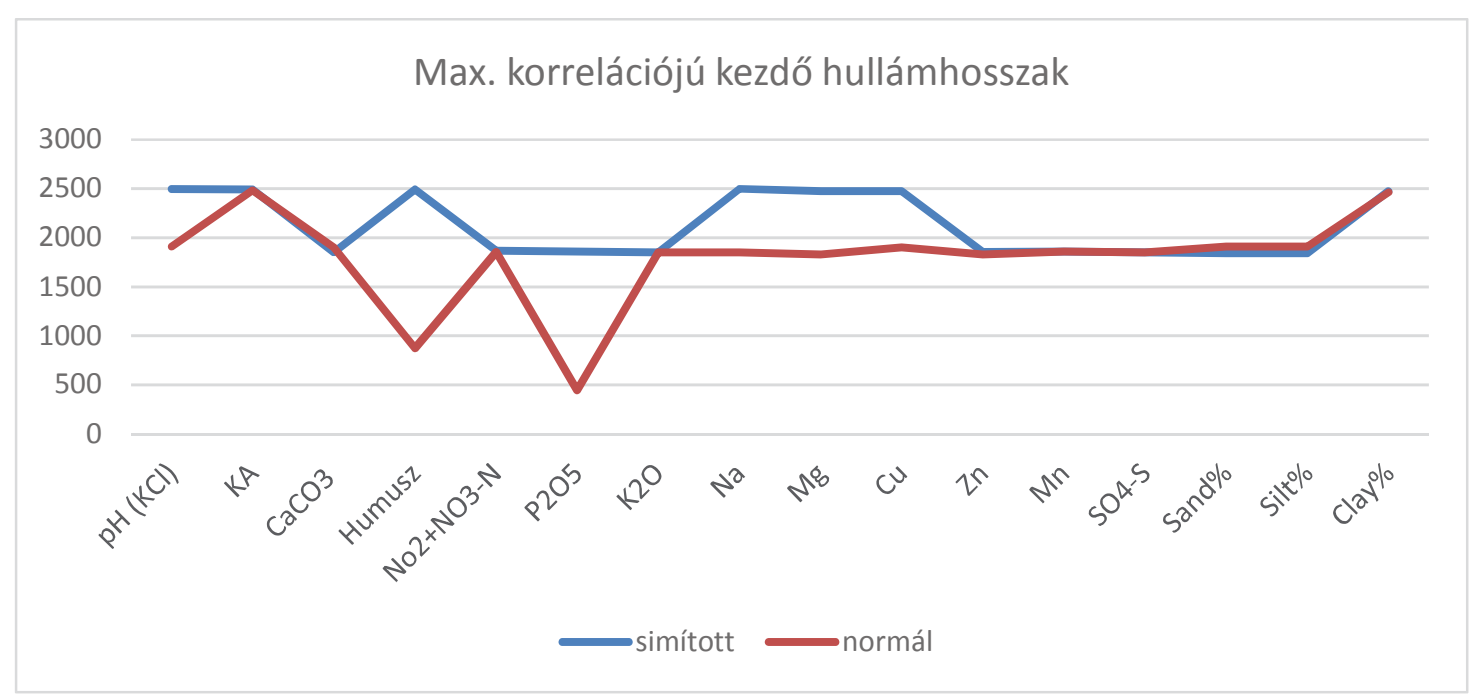

8. ábra. A labor adatra leginkább érzékeny hullámhosszak simított/normál talaj esetén

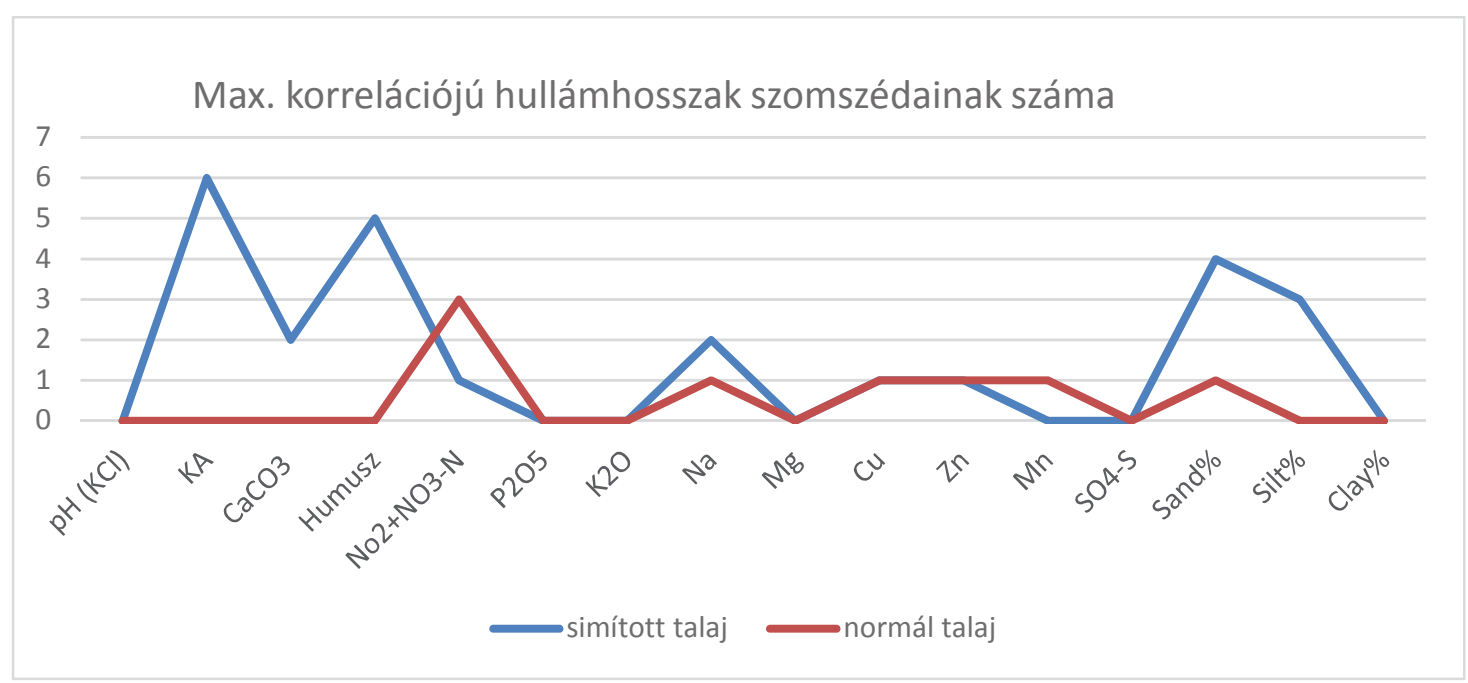

9. ábra. A max. korrelációnál figyelembe vett szomszédos hullámhosszak száma

\section{A laboradatok becslése a hiperspektrális adatokból}

Az előző fejezetben láttuk, hogy bizonyos spektrális adatsorok (illetve azok átlaga) jól korrelálnak a labor-adatokkal. A jó korreláció viszont közelítőleg lineáris kapcsolatot feltételez az adatsorok között, ami regressziós egyenes illesztéssel meghatározható. A kutatás zárásaként meghatároztuk a simított talaj és a talajparaméterek legjobb korrelációjánál érvényes egyenes-illesztés (lineáris regresszió) paramétereit és hibáját, amit a 2. táblázatban foglaltunk össze: 


\begin{tabular}{|l||c|c|r|r|r|r||}
\hline Talaj attributum & kezdő hh & utolsó hh & korreláció & m* intenzitás & + konstans & átlagos hiba \\
\hline \hline pH (KCl) & 2494 & 2494 & 0,744047445 & 0,945893825 & 7,17114112 & 0,086870166 \\
\hline KA & 2493 & 2499 & $-0,822401438$ & $-41,38217159$ & 55,002649 & 2,589002186 \\
\hline CaCO3 & 1851 & 1853 & 0,758058768 & 14,27983081 & 11,3285781 & 2,048742253 \\
\hline Humusz & 2492 & 2497 & $-0,821470332$ & $-3,611737425$ & 3,33340928 & 0,199029439 \\
\hline No2+NO3-N & 1870 & 1870 & 0,570430331 & 9,2108647 & 3,36817544 & 4,757651887 \\
\hline P2O5 & 1872 & 1872 & 0,717323014 & 147,3655419 & 134,48017 & 33,58685803 \\
\hline K2O & 1849 & 1849 & $-0,768248319$ & $-277,4079628$ & 384,851677 & 67,88898619 \\
\hline Na & 2498 & 2500 & 0,583522484 & 91,4145948 & 29,1253924 & 17,5190072 \\
\hline Mg & 2475 & 2475 & $-0,881730636$ & $-1371,854066$ & 651,107612 & 37,22532888 \\
\hline Cu & 2474 & 2475 & $-0,771962518$ & $-23,91006587$ & 12,307372 & 1,002542246 \\
\hline Zn & 1908 & 1912 & 0,770431108 & 4,54802179 & 1,09366512 & 0,350396624 \\
\hline Mn & 1868 & 1868 & $-0,46224779$ & $-19,02886049$ & 32,5268205 & 11,83677712 \\
\hline SO4-S & 1849 & 1849 & $-0,773230494$ & $-17,0688913$ & 31,3539888 & 4,111215183 \\
\hline Sand\% & 1841 & 1846 & 0,912975388 & 53,92367293 & 4,75521429 & 5,204997516 \\
\hline Silt\% & 1842 & 1845 & $-0,88239173$ & $-33,17047645$ & 69,0639769 & 4,36215317 \\
\hline Clay\% & 2475 & 2475 & $-0,870358686$ & $-73,32830072$ & 40,716835 & 2,104065309 \\
\hline
\end{tabular}

2. táblázat. A lineáris regresszió paraméterei és hibája

Már utaltunk rá, ha szélesebb összefüggő tartományban detektálunk, akkor a spektrális adatok átlagolása javítja a hibatürést. A talajparaméterek többségénél a legjobb korrelációt egyedi, nem szomszédos hullámhosszakon kaptuk, ezzel ez a hibajavító opció kiesett. Megvizsgáltuk ezért, ha megelégszünk az optimálisnál legfeljebb 0,1-el kisebb korrelációval, tudjuk-e növelni a detektáló tartomány hosszát. A válasz természetesen igen, és az eredményeket a 3. táblázat tartalmazza.

A regisztrálandó spektrális tartományok - természetesen most is simított talajnál - (1826, 1916) és (2476, 2500)-ra nőttek. Az alacsonyabb korreláció miatt a lineáris becslés átlaghibája ugyan nőtt, de az eljárás robusztusabb lett; az átlagszámítás miatt kevésbé érzékeny az egyedi mérési hibákra.

\begin{tabular}{||l||c|r|r|r|r|r||}
\hline Talaj attribútum & kezdő hh & utolsó hh & korreláció & m * intenzitás & + konstans & átlagos hiba \\
\hline \hline pH $($ KCl) & 2492 & 2496 & 0,7141035 & 0,965679365 & 7,15539451 & 0,091019558 \\
\hline KA & 2491 & 2500 & $-0,746042$ & $-37,98773274$ & 53,7732071 & 3,030392961 \\
\hline CaCO3 & 1826 & 1835 & 0,5611566 & 25,33492736 & 7,8283256 & 2,478766134 \\
\hline Humusz & 2490 & 2499 & $-0,8414135$ & $-3,482238028$ & 3,31550214 & 0,188607857 \\
\hline No2+NO3-N & 1869 & 1872 & 0,6546498 & 10,4461466 & 3,10281759 & 3,176786172 \\
\hline P2O5 & 2479 & 2481 & 0,6254813 & 520,5185891 & 27,350564 & 37,61195169 \\
\hline K2O & 1848 & 1849 & $-0,7385674$ & $-322,6904595$ & 406,782762 & 71,49766462 \\
\hline Na & 2497 & 2500 & 0,585624 & 97,00546181 & 28,3045939 & 17,48634292 \\
\hline Mg & 2473 & 2476 & $-0,8411375$ & $-1285,975252$ & 620,6395504 & 42,67538593 \\
\hline Cu & 2490 & 2499 & $-0,7376959$ & $-13,79582055$ & 8,4239765 & 1,064784557 \\
\hline Zn & 1907 & 1916 & 0,6555008 & 4,634827774 & 1,10977595 & 0,415071272 \\
\hline Mn & 1868 & 1869 & 0,5099243 & 28,00535249 & 14,5632884 & 11,72269405 \\
\hline SO4-S & 1848 & 1849 & $-0,7438687$ & $-19,86878481$ & 32,7100108 & 4,332948023 \\
\hline Sand \% & 1841 & 1850 & 0,822889 & 43,71973523 & 8,96588654 & 7,24849115 \\
\hline Silt\% & 1841 & 1850 & $-0,8030664$ & $-31,00772199$ & 69,1223839 & 5,524497619 \\
\hline CLAY \% & 2473 & 2476 & $-0,8115942$ & $-67,19020033$ & 38,55142629 & 2,496333399 \\
\hline
\end{tabular}

3. táblázat. A bővített tartományú lineáris regresszió és hibája 


\section{6. Összefoglaló}

A talajmintákat vettünk és hiperspektrális felvételeket készítettünk mezőgazdasági müvelésű parcellák ugyanazon mintavételi helyein. Korrelációszámítással határoztuk meg, hogy az egyes talaj-összetevők mely hullámhossz tartományokon mutathatók ki a legbiztosabban, illetve regresszió-analízissel következtettünk a hiperspektrális képekböl a talajparaméterek mennyiségére. Ajánlást adtunk a felvételek készítésének körülményeire is. Megállapítottuk, hogy a felvételek pontosságvesztés nélkül készíthetők olcsóbb multispektrális kamerákkal is.

\section{Köszönetnyilvánítás.}

Kutatásainkat a VKSZ_12-1-2013-0034 Klíma2 pályázat támogatta.

\section{Irodalomjegyzék}

[1] E Ben-Dor, Y Benyamini, N Goldlschleger, M Agassi: The Spectral Reflectance Properties of Soil Structural Crusts in the 1.2- to 2.5- $\mu \mathrm{m}$ Spectral Region, in Soil Science Society of America Journal 67(1), January 2003. doi:10.2136/sssaj2003.0289

[2] G Grandjean, I Cousin, M Seger, J Thiesson, S Lambot, B Van Wesemael, A Stevens, K Samyn, A Bitri, S Bernardie, 2009. From geophysical parameters to soil characteristics, Report N $^{\circ} \mathrm{BRGM} / \mathrm{FP} 7-$ DIGISOIL-D2.1, 52 pages. https://esdac.jrc.ec.europa.eu/public_path/Digisoil-D2.1.pdf 